[Regular Paper]

\title{
Liquid Phase Hydrogenation of Carbon Monoxide Using Ultrafine Particles of Cobalt as Catalyst
}

\author{
Takeshi Matsuda*, Ryoji Sorita, and Eiichi KıкUchi \\ Dept. of Applied Chemistry, School of Science \& Engineering, \\ Waseda University, 3-4-1 Okubo, Shinjuku-ku, Tokyo 169
}

(Received November 30, 1992)

\begin{abstract}
Liquid phase Fischer-Tropsch synthesis was investigated with ultrafine particles (UFP) composed of Co. The catalytic activity of Co UFP was higher than that of precipitated Co catalyst. Apparent activation energies on Co UFP and the precipitated Co were found to be 16 , and $10 \mathrm{kcal} / \mathrm{mol}$, respectively. Furthermore, Co UFP exhibited very low selectivity for methane formation compared with the precipitated catalyst. The activity and selectivity of Co catalyst supported on $\mathrm{SiO}_{2}$ for production of higher hydrocarbons increased, and the apparent activation energy increased with increasing pore diameter of $\mathrm{SiO}_{2}$ support. These results indicated that the reaction on the precipitated catalyst was affected by diffusion of the reactant into the pores. We conclude that nonporous structure of Co UFP provided high catalytic activity and selectivity for higher hydrocarbons.
\end{abstract}

\section{Introduction}

Fischer-Tropsch (FT) synthesis is accompanied by an extremely large heat evolution. To improve the characteristics of heat transfer, liquid (slurry) phase synthesis has been developed ${ }^{11}$. In the liquid phase synthesis, the solvent efficiently removes the heat of reaction so that the steady state reaction can easily be achieved. Furthermore, waxy heavy hydrocarbons can be removed from the catalyst surface by action of the solvent, so that high catalytic activity can be maintained.

Although pulverized Fe catalysts were used in the past studies on liquid phase synthesis, we have studied the application of ultrafine particles (UFP) as a catalyst for enhancing the gas-liquid solid interface contact in a slurry reactor ${ }^{2) \sim 4)}$, and it has been found that Fe UFP is catalytically more active and selective for production of liquid hydrocarbon fuels than ordinary precipitated $\mathrm{Fe}$ catalyst. It has been shown in our previous works that the catalytic activity of Fe UFP for liquid phase FT synthesis is significantly enhanced by the addition of alkali metal ${ }^{5)}$ and copper(6),7). We have also reported $^{8)}$ that the selectivity for olefin production of Fe UFP catalyst has been effectively promoted by fine particles of $\mathrm{Mn}$ oxide additive.

Apart from several catalyst formulations of $\mathrm{Fe}$ catalysts, considerable interest has been shown in Co-based catalysts for production of higher

* To whom correspondence should be addressed. hydrocarbons. Co-based catalysts exhibit low selectivity for carbon dioxide formation compared with Fe-based catalysts. The objective of this study is to determine the catalytic activity and selectivity of Co UFP for the liquid phase FT synthesis in comparison with ordinary precipitated Co catalysts.

\section{Experimental}

\section{1. Apparatus and Procedures}

Hydrogenation of carbon monoxide was carried out in a high pressure flow system equipped with a stirred slurry-bed reactor in the temperature range from 220 to $270^{\circ} \mathrm{C}$ and at $30 \mathrm{~atm}(1 \mathrm{~atm}=101 \mathrm{kPa})$. Syngas with a hydrogen-to-carbon monoxide molar ratio of 2 was fed to the bottom of the reactor through a nozzle and was allowed to react on the catalyst suspended in hexadecane. An ultrasonic generator was used to prepare a suspension of the catalyst prior to FT reaction. The experimental apparatus for the synthesis and the analytical procedure were reported previously7).

\section{Catalyst}

Co UFP and precipitated Co catalysts were used in the present study. The Co UFP was supplied by Vacuum Metallurgical Co., Ltd. and was prepared by the gas evaporation method. This UFP had a nonporous structure and the BET surface area of $32.3 \mathrm{~m}^{2} / \mathrm{g}$, according to the average 
Table 1 Physical Properties of $\mathrm{SiO}_{2}$

\begin{tabular}{cccc}
\hline $\mathrm{SiO}_{2}$ & $\begin{array}{c}\text { Average pore size } \\
{[\AA]}\end{array}$ & $\begin{array}{c}\text { Surface area } \\
{\left[\mathrm{m}^{2} \cdot \mathrm{g}^{-1}\right]}\end{array}$ & $\begin{array}{c}\text { Pore volume } \\
{\left[\mathrm{ml} \cdot \mathrm{g}^{-1}\right]}\end{array}$ \\
\hline 1 & 100 & 300 & 1.05 \\
2 & 300 & 100 & 1.05 \\
3 & 500 & 90 & 1.05 \\
\hline
\end{tabular}

particle size of $204 \AA$ ( $\left.1 \AA=10^{-10} \mathrm{~m}\right)$, which was determined by TEM observations. The X-ray diffraction analysis of the UFP gave diffraction peaks due only to $\alpha$-Co (cubic).

The precipitated Co catalyst composed of 100Co: $18 \mathrm{MgO}: 200$ diatom earth (weight ratio) was prepared according to the method described by Anderson and co-workers ${ }^{9}$. The precipitated Co catalyst was also prepared using $\mathrm{SiO}_{2}$ obtained by Fuji Davison Co., Ltd. instead of diatom earth. The physical properties of $\mathrm{SiO}_{2}$ used in this study are summarized in Table 1. The $\mathrm{SiO}_{2}$ support used here had a similar pore volume and different pore diameter. After drying at $110^{\circ} \mathrm{C}$, the precipitated Co catalyst was finely crushed to powders and activated in a stream of hydrogen at $400^{\circ} \mathrm{C}$ for $2 \mathrm{~h}$.

The number of catalytically active sites of Co UFP was calculated from the particle size, and that of the precipitated Co was determined from the chemisorptive uptakes of carbon monoxide measured at $25^{\circ} \mathrm{C}$ using a conventional statistic apparatus.

\section{Results and Discussion}

Figure 1 shows the variation in the level of carbon monoxide conversion on these catalysts with time on stream. The activities of these catalysts scarcely changed for $5 \mathrm{~h}$ in this temperature range. The space time yield (STY) of hydrocarbons and carbon distribution in the product for the initial $5 \mathrm{~h}$ of run are summarized in Table 2. The STY of hydrocarbons on UFP increased from 1.4 to $6.6 \mathrm{~g} \cdot \mathrm{Co}-\mathrm{g}^{-1} \cdot \mathrm{h}^{-1}$ with increasing reaction temperature from 220 to $270^{\circ} \mathrm{C}$. The precipitated Co catalyst composed of 100Co: $18 \mathrm{MgO}: 200$ diatom earth has been re-

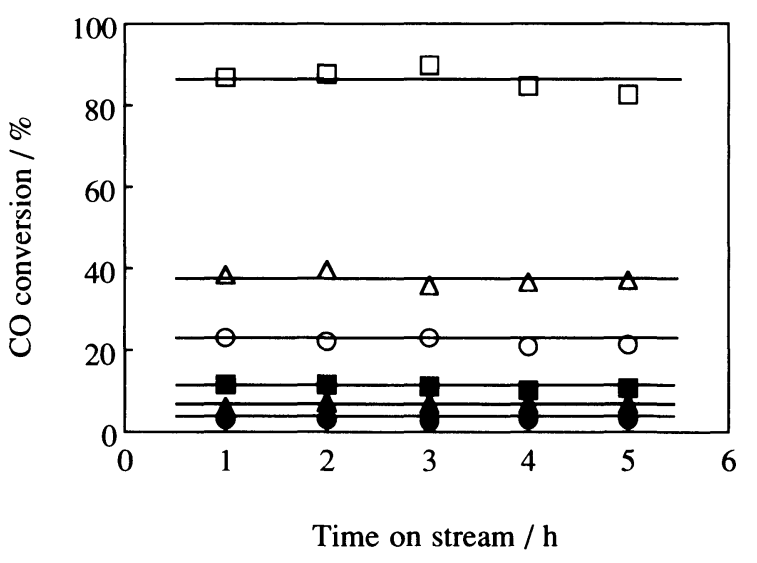

Reaction conditions: temperature $\bigcirc, 220^{\circ} \mathrm{C} ; \Delta \boldsymbol{\Delta}, 240^{\circ} \mathrm{C}$; $\square \square, 270^{\circ} \mathrm{C}$

pressure, $30 \mathrm{~kg} / \mathrm{cm}^{2} ; \mathrm{H}_{2} / \mathrm{CO}$ molar ratio, $2 ; W / F, 100$ g-cat.min/CO-mol.

Fig. l Variation in the Level of CO Conversion on Co UFP (open symbols) and $\mathrm{Co}-\mathrm{MgO} /$ diatom earth (solid symbols) Catalysts with Time on Stream

ported to be highly active for gas phase FT synthesis ${ }^{9}$; however, when compared for the liquid phase reaction, the Co UFP provided greater STY of hydrocarbons than the precipitated catalyst, particularly at $270^{\circ} \mathrm{C}$. The selectivities of Co UFP for carbon dioxide and oxygenated organic compounds were low, and hydrocarbons were selectively formed even at $270^{\circ} \mathrm{C}$.

Figure 2 shows Arrhenius plots for Co UFP and the precipitated Co catalysts. The apparent activation energies on UFP and precipitated catalysts were found to be 16 and $10 \mathrm{kcal} \cdot \mathrm{mol}^{-1}$, respectively. It is generally known that apparent activation energy is markedly lowered when the rate of reaction is affected by diffusion of the reactant. In the case of catalysts having porous structures, the reactant diffuses into the pores, and then reacts on the catalyst surface. If the catalytic reaction is faster than the diffusion process, the concentration of reactant falls away with distance from the pore mouth. Thus, a limited portion of the catalyst

Table 2 Catalytic Activities and Selectivities of Co UFP and $\mathrm{Co}-\mathrm{MgO} /$ diatom earth

\begin{tabular}{|c|c|c|c|c|c|c|}
\hline \multirow{2}{*}{$\begin{array}{l}\text { Catalyst } \\
\text { Temperature }\end{array}$} & \multicolumn{3}{|c|}{ Co UFP } & \multicolumn{3}{|c|}{ Co pptd. } \\
\hline & 220 & 240 & 270 & 220 & 240 & 270 \\
\hline CO conversion & 22.0 & 37.5 & 86.3 & 4.0 & 6.7 & 11.0 \\
\hline STY $\quad\left[\mathrm{g} \cdot \mathrm{Co}^{-\mathrm{g}^{-1}} \cdot \mathrm{h}^{-1}\right]$ & 1.4 & 2.4 & 6.6 & 1.0 & 1.7 & 2.8 \\
\hline Selectivity $\quad[\mathrm{C}-\%]$ & & & & & & \\
\hline Hydrocarbons & 98.9 & 97.3 & 89.0 & 100 & 99.4 & 97.1 \\
\hline Oxygenates & 1.0 & 0.8 & 0.5 & 0 & 0.6 & 0.7 \\
\hline $\mathrm{CO}_{2}$ & 0.1 & 1.9 & 10.5 & 0 & 0 & 1.9 \\
\hline
\end{tabular}


Table 3 Catalytic Activities and Selectivities of Co Catalysts Supported on $\mathrm{SiO}_{2}$

\begin{tabular}{lrccc}
\hline \multicolumn{1}{c}{ Catalysts } & $\mathrm{Co}-\mathrm{MgO} / 100 \AA \mathrm{SiO}_{2}$ & $\mathrm{Co}-\mathrm{MgO} / 300 \AA_{\mathrm{SiO}}$ & $\mathrm{Co}-\mathrm{MgO} / 500 \AA \mathrm{SiO}_{2}$ \\
\hline CO conversion & {$[\%]$} & 12.3 & 17.4 & 27.6 \\
$\mathrm{STY}$ & {$\left[\mathrm{g} \cdot \mathrm{Co}^{-1} \cdot \mathrm{h}^{-1}\right]$} & 3.1 & 4.2 & 5.7 \\
Activation energy & {$\left[\mathrm{kcal} \cdot \mathrm{mol}^{-1}\right]$} & 10.8 & 11.3 & 14.6 \\
Selectivity & {$[\mathrm{C}-\%]$} & & 96.6 & 97.2 \\
Hydrocarbon & & 97.4 & 1.0 & 0.3 \\
Oxygenates & 0.7 & 2.4 & 2.5 \\
$\mathrm{CO}_{2}$ & 1.9 & & \\
\hline
\end{tabular}

Reaction conditions: temperature, $270^{\circ} \mathrm{C}$; pressure, $30 \mathrm{~kg} / \mathrm{cm}^{2} ; W / F, 100$ g-cat.min $/ \mathrm{CO}$-mol; $\mathrm{H}_{2} / \mathrm{CO}$ molar ratio, 2.

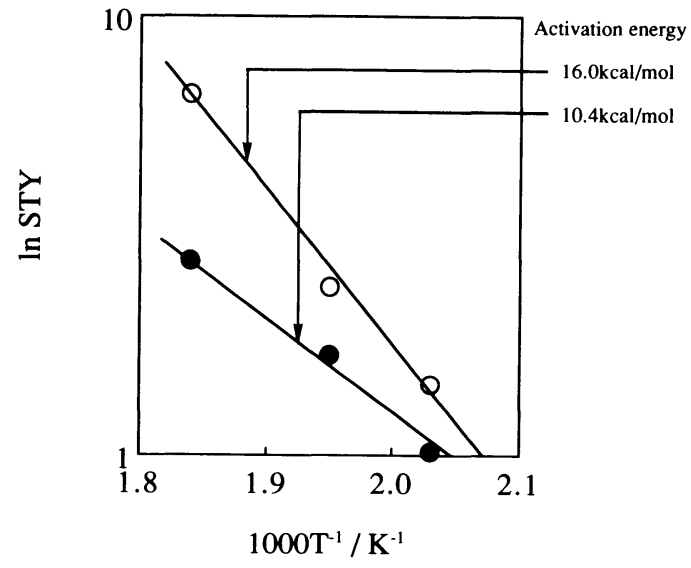

Reaction conditions: pressure, $30 \mathrm{~kg} / \mathrm{cm}^{2} ; W / F, 100 \mathrm{~g}$. cat.min/CO-mol; $\mathrm{H}_{2} / \mathrm{CO}$ molar ratio, 2.

Fig. 2 Arrhenius Plot for Co UFP (O) and $\mathrm{Co}-\mathrm{MgO} /$ diatom earth $(\mathbf{O})$ Catalysts

surface can be used for reaction. As Co UFP has a nonporous structure, the diffusion process does not seem to affect the activity of Co UFP catalyst for the liquid phase FT synthesis.

In order to understand the effects of diffusion process on the activity of Co catalyst, the liquid phase FT synthesis was carried out using three precipitated Co catalysts supported on $\mathrm{SiO}_{2}$ having different pore size. Typical results are summarized in Table 3. The STY of hydrocarbons and apparent activation energy were enlarged by increasing pore diameter of $\mathrm{SiO}_{2}$ support. As mentioned above, a limited portion of the catalyst surface is used for reaction when the catalyst has a porous structure. Thus, the difference in the activity shown in Table 3 can be explained by taking the diffusion process into consideration. We conclude from these results that nonporous structure of Co UFP provides high catalytic activity for liquid phase FT synthesis.

Figure 3 shows product distribution of hydrocarbons produced on UFP and precipitated catalysts. As shown in this figure, the UFP catalyst was more selective for longer chain

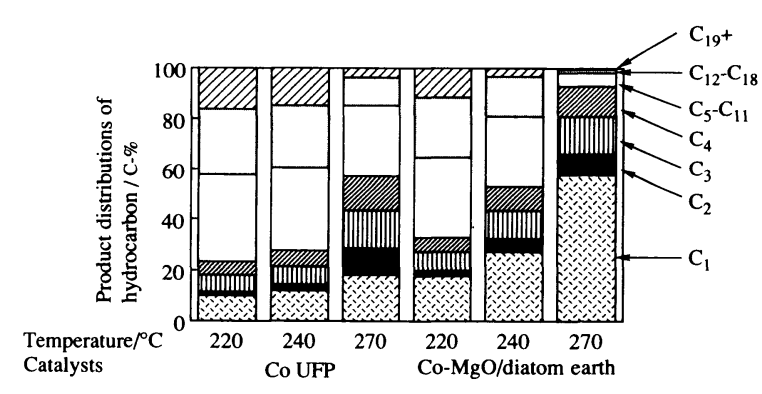

Reaction conditions: pressure, $30 \mathrm{~kg} / \mathrm{cm}^{2} ; \mathrm{H}_{2} / \mathrm{CO}$ molar ratio, $2 ; W / F, 100$ g-cat. $\mathrm{min} / \mathrm{CO}$ mol.

Fig. 3 Product Distributions of Hydrocarbons Produced on Co Catalysts

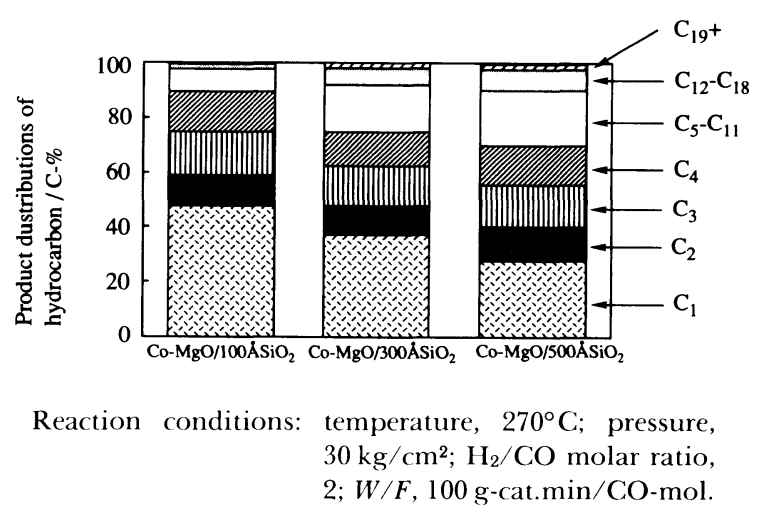

Fig. 4 Product Distributions of Hydrocarbons Produced on Co Catalysts Supported on $\mathrm{SiO}_{2}$

hydrocarbon production than the precipitated catalyst. The chain growth probabilities on the UFP at 220,240 , and $270^{\circ} \mathrm{C}$ were $0.85,0.84$, and 0.83 , respectively, while on the precipitated catalyst, they were $0.78,0.75$, and 0.72 at these temperatures. The precipitated catalyst exhibited high selectivity for methane formation, particularly at $270^{\circ} \mathrm{C}$.

Product distributions of hydrocarbons on the precipitated Co catalysts supported on $\mathrm{SiO}_{2}$ are shown in Fig. 4. The selectivity for methane decreased and that for higher hydrocarbons 
Table 4 Particle Size, Number of Active Sites and Specific Activity of Co Catalysts

\begin{tabular}{lccc}
\hline \multicolumn{1}{c}{ Catalysts } & $\begin{array}{c}\text { Particle size } \\
{[\AA]}\end{array}$ & $\begin{array}{c}\text { Number of active sites } \\
{\left[10^{19} \mathrm{Co}-\mathrm{g}^{-1}\right]}\end{array}$ & $\begin{array}{c}\mathrm{STY} / \text { number of active sites } \\
{\left[\mathrm{g} \cdot \mathrm{h}^{-1} \cdot 10^{20}\right]}\end{array}$ \\
\hline $\mathrm{Co} \mathrm{UFP}$ & 204 & 48.6 & 1.4 \\
$\mathrm{Co}-\mathrm{MgO} /$ diatom earth & 567 & 17.5 & 1.6 \\
$\mathrm{Co}-\mathrm{MgO} / 100 \AA \mathrm{SiO}_{2}$ & 580 & 17.1 & 1.8 \\
$\mathrm{Co}-\mathrm{MgO} / 300 \AA \mathrm{SiO}_{2}$ & 627 & 15.8 & 2.6 \\
$\mathrm{Co}-\mathrm{MgO} / 500 \AA \mathrm{SiO}_{2}$ & 636 & 15.6 & 3.7 \\
\hline
\end{tabular}

Reaction conditions: temperature, $270^{\circ} \mathrm{C}$; pressure, $30 \mathrm{~kg} / \mathrm{cm}^{2} ; W / \mathrm{F}, \mathrm{l} 00 \mathrm{~g}$-cat.min $/ \mathrm{CO}$-mol; $\mathrm{H}_{2} / \mathrm{CO} \mathrm{molar}$ ratio, 2.

increased with increasing pore diameter. The difference in the product distributions in Figs. 3 and 4 can be interpreted by taking the diffusion process into consideration. The selectivity for higher hydrocarbons decreased and that for methane increased with increasing $W / F$. We deduce that the residence time of hydrocarbons produced in the pore is increased by decreasing size of pore diameter, and consequently the product distribution shifts toward shorter chain hydrocarbons and the selectivity for methane increases. It is also possible to explain the results shown in Figs. 3 and 4 by diffusion of the reactant. When its diffusion is slow, the rate of desorption becomes fast compared with that of chain growth, resulting in high selectivities for methane and shorter chain hydrocarbons. We conclude from these results that the high selectivity of Co UFP for the formation of higher hydrocarbons is related to its nonporous structure.

Table 4 shows the particle sizes of Co, the number of active sites, and the STY of hydrocarbons per active site. Among the catalysts tested, Co UFP had the smallest particle size, and the largest number of active sites. Thus, the highest catalytic activity of Co UFP seems to be related to the small size of its particles as well as its nonporous structure. As the rate of reaction on precipitated Co catalyst is controlled by diffusion of the reactant, Co UFP should provide greater STY than the precipitated catalyst when compared at certain number of active sites. The STY of hydrocarbons on UFP catalyst, however, was smaller than that on other catalysts. The activity of Co catalyst has been known to be enhanced by addition of $\mathrm{MgO}$ or $\mathrm{ThO}_{2}$. The low activity of Co UFP seems to be caused by absence of $\mathrm{MgO}$.

The STY of hydrocarbons on supported Co catalysts increased with increasing pore size of $\mathrm{SiO}_{2}$. Johnson et al. ${ }^{10}$ ) and Hercules et al. ${ }^{11)}$ reported that the activity of supported Co catalyst was independent of the particle size when the activity was compared at certain number of active sites. In contrast, it was shown by Bartholomew and co-workers ${ }^{12), 13)}$ that the activity of supported Co catalyst decreased $1-2$ orders of magnitude with decreasing particle size. They reported that hydrogenation of carbon monoxide was structure insensitive on a well-reduced Co catalyst, while the hydrogenation was structure sensitive on a lowpercentage reduced Co catalyst. The supported catalysts used in this study exhibited high percentage of reduction, and had well-reduced Co surfaces. As shown in Table 3, the apparent activation energy increased with increasing pore size of $\mathrm{SiO}_{2}$ support. Therefore, the difference in the activity among the supported catalysts is interpreted as due to diffusion limitation.

\section{Conclusion}

Liquid phase Fischer-Tropsch synthesis was investigated with ultrafine particles (UFP) composed of Co, which was prepared by the gas evaporation method. Co UFP catalyst was more active than the precipitated Co catalyst. Furthermore, Co UFP exhibited very low selectivity for methane and high selectivity for formation of higher hydrocarbons compared with the precipitated catalyst. Co UFP gave greater apparent activation energy than the precipitated Co, indicating that diffusion process affected the reaction on the precipitated catalyst. The activity and selectivity of $\mathrm{Co}$ catalyst supported on $\mathrm{SiO}_{2}$ were varied with the surface structure of the support. The supported Co catalyst showed high activity and selectivity for production of higher hydrocarbons when $\mathrm{SiO}_{2}$ having larger pores was used as a support. We conclude from these results that nonporous structure of Co UFP provides high catalytic activity and selectivity for production of higher hydrocarbons.

\section{References}

1) Kolbel, H., Ralek, M., Catal. Rev.-Sci. Eng., 21, 225 (1980).

2) Itoh, H., Hosaka, H., Ono, T., Kikuchi, E., Appl. Catal., 40, 53 (1988)

3) Kikuchi, E., Itoh, H., Sekiyu Gakkaishi, 34, (5), 407 (1991).

4) Kikuchi, E., Itoh, H., Stud. Surf. Sci. Catal., 36, 517 (1989).

5) Itoh, H., Ono, T., Nagano, S., Kikuchi, E., Sekiyu Gakkaishi, 32, (6), 319 (1989).

6) Itoh, H., Tanabe, H., Kikuchi, E., Appl. Catal., 47, Ll 
(1989).

7) Itoh, H., Kikuchi, E., Appl. Catal., 67, 1 (1991).

8) Itoh, H., Nagano, S., Urata, T., Kikuchi, E., Appl. Catal., 77, 37 (1991).

9) Anderson, R. B., Krieg, A., Seligman, B., Oneill, W. E., Ind. Eng. Chem., 39, 548 (1947).
10) Johnson, B. G., Bartholomew, C. H., Goodman, D. W., J. Catal., 128, 231 (1991).

11) Ho, S. W., Houalla, M., Hercules, D. M., J. Phys. Chem., 94, 6395 (1990).

12) Reuel, R. C., Bartholomew, C. H., J. Catal., 85, 78 (1984).

13) Fu, I., Bartholomew, C. H., J. Catal., 92, 376 (1985).

要旨

\section{コバルト超微粒子を用いた一酸化炭秦の液相水秦化}

松田 剛, 反田亮史, 菊地英一

早稲田大学理工学部応用化学科, 169 東京都新宿区大久保 3-4-1

ガス中蒸発法で調製した Co 超微粒子(UFP)触媒を用いて, 液相フィッシャー・トロプシュ(FT)合成を行った。

UFP 触媒と沈殿 Co 触媒で Co 重量当たりの炭化水素の空 時収率(STY)を比較すると, UFP 触媒は沈殿 Co 触媒の 1.4 2.4 倍高い值を示した。また, みかけの活性化エネルギーは UFP 触媒で $16 \mathrm{kcal} / \mathrm{mol}$, 沈殿 Co 触媒では $10 \mathrm{kcal} / \mathrm{mol}$ と UFP 触媒の方が高い值を示した。このことは沈殿 Co 触媒で は細孔内拡散が遅い過程になっていることを示唆している。

細孔内拡散の影響を検討するために, 細孔径の異なる $\mathrm{SiO}_{2}$ を用いて沈殿 Co 触媒を調製し活性試験を行った。その結 果, Co 重量当たりの STY, 見かけの活性化エネルギーは $\mathrm{SiO}_{2}$ の細孔径の大きい触媒ほど大きくなっており, $\mathrm{SiO}_{2}$ の細 孔径と STY, 見かけの活性化エネルギーの間には相関がある
ことが示された。このことより，UFP 触媒は非細孔性のため に沈殿 Co 触媒よりも高い活性を示すと考察した。

UFP 触媒ではメタン生成の選択性が低く, 高沸点炭化水素 が高い選択率で生成した。沈殿 Co 触媒では, 細孔径の大きな $\mathrm{SiO}_{2}$ を用いた触媒ほど高沸点炭化水素の選択性が高くなっ た。これは細孔径の大きい $\mathrm{SiO}_{2}$ を用いた触媒ほど, 生成物の 拡散速度が大きく細孔内に滞留している時間が短くなり, 水素 化や水素化分解などの二次的反応の影響を受けにくくなるため と考えられる。

以上のことょり, Co UFP 触媒は非細孔性のために液相 FT 合成に高い活性を示し, 高沸点炭化水素の生成に高い選択性を 示すと結論した。

\section{Keywords}

Fischer-Tropsch synthesis, Liquid phase reaction, Ultrafine particle, Cobalt catalyst, Diffusion limitation,

Nonporous structure 